\title{
PROFILE OF STUDENTS' FLEXIBILITY IN SOLVING LINEAR EQUATIONS IN ONE VARIABLE
}

\author{
Alfia Mahardika \\ Mathematics Education, Faculty of Matematics and Natural Sciences, Universitas Negeri Surabaya \\ e-mail: alfiamahardika16030174086@mhs.unesa.ac.id \\ Abdul Haris Rosyidi \\ Mathematics Education, Faculty of Matematics and Natural Sciences, Universitas Negeri Surabaya \\ e-mail: abdulharis@unesa.ac.id
}

\begin{abstract}
Flexibility is the ability to solve problems with more than one solution and the ability to choose the most appropriate procedure. This study aims to describe the profile of students' flexibility in solving linear equations in one variable. Three students of grade VIII from a Junior High School in Surabaya were selected as subjects in this study with the criteria that one student could solve the problem in one solution, one student could solve the problem in two solutions, one student could solve the problem in three solutions. The instruments used were researcher, test, and interview guidelines. Data analysis was performed descriptively qualitatively through data reduction, data presentation, and making conclusions. The results showed students tend to choose the method of settlement commonly used to solve problems even though they have gained experience about alternative solutions. The settlement method was chosen as the most appropriate solution is the commonly used solution despite knowing other more effective solutions. That is because students choose to use solutions they already understand to avoid confusion. In learning linear equations in one variable students should be given space to identify and choose the most effective solutions to solve linear equations in one variable while providing arguments related to that choice.
\end{abstract}

Keywords: flexibility, linear equations in one variable, procedural knowledge, conceptual knowledge

\section{Abstrak}

Fleksibilitas adalah kemampuan untuk menyelesaian soal menggunakan lebih dari satu cara penyelesaian dan kemampuan dalam memilih prosedur yang paling tepat. Penelitian ini bertujuan untuk mendeskripsikan profil fleksibilitas siswa dalam menyelesaikan persamaan linear satu variabel. Tiga siswa kelas VIII dari salah satu Sekolah Menengah Pertama di Surabaya dipilih sebagai subjek dalam penelitian ini dengan kriteria satu siswa dapat menyelesaikan soal dengan satu cara, satu siswa dapat menyelesaikan soal dengan dua cara, satu siswa dapat menyelesaikan soal dengan tiga cara. Instrumen yang digunakan berupa peneliti, soal tes, dan pedoman wawancara. Analisis data dilakukan secara deskriptif kualitatif melalui pereduksian data, penyajian data, dan penarikan kesimpulan. Hasil penelitian menunjukkan bahwa siswa cenderung memilih metode penyelesaian yang biasa digunakan untuk menyelesaian soal meskipun telah memperoleh pengalaman tentang metode alternatif. Cara penyelesaian yang dipilih sebagai cara yang paling tepat adalah cara yang biasa digunakan walaupun mengetahui ada cara penyelesaian lain yang lebih efektif. Hal tersebut dikarenakan siswa memilih untuk menggunakan cara yang telah mereka pahami untuk menghindari kebingungan. Dalam pembelajaran persamaan linear satu variabel siswa seharusnya diberi ruang untuk mengidentifikasi dan memilih cara yang paling efektif untuk menyelesaikan persamaan linear satu variabel sekaligus memberi argumen terkait pilihan tersebut.

Kata Kunci: fleksibilitas, persamaan linear satu variabel, pengetahuan prosedural, pengetahuan konseptual

\section{INTRODUCTION}

Mathematics is a science like physics or astronomy which is based on facts, obtained from reliable methods, verified by practice, and approved by quality consensus (Hersh, 2019). The difference between mathematics and other sciences is that the object is not empirical and lives in its own independent realm. The subject of mathematics is in the form of ideas and concepts that only exist in human consciousness. Dieks (2014) further reflects the success of mathematics and physics to find the difference between the nature of mathematics and the nature of physics allows mathematics to be very flexible and easily adapt to various needs. A number of examples that can be seen from basic physics illustrate how mathematics through its flexibility and versatility achieves its great effectiveness.

One important aspect needed to be successful in learning mathematics is effective teaching where the implementation involves students in meaningful learning and collaborative experiences that can encourage them to 
understand ideas and mathematical reasoning (NCTM, 2014). According to the National Council of Teachers of Mathematics (2014) say that effective mathematics learning was built from procedural fluency based on conceptual understanding so students from time to time were trained to use procedures flexibly to further be applied in solving various problems and mathematical contexts.

For decades, there have been many studies in the field of mathematics education that have an interest in the relationship between procedural knowledge and conceptual knowledge (Byrnes \& Wasik, 1991; Hiebert, 1986; Rittle Johnson, Siegler, \& Alibali, 2001). Newton and Star (2010) have explored how the two types of knowledge are linked, including which developed first, or whether one knowledge is intended for another. In particular, Star (2005) argues that procedural knowledge is often understood and measured in ways that are consistent with memorization. Whereas conceptual knowledge includes deep knowledge. Star (2005) suggests that procedural knowledge can also be in depth as it should be flexibly applying the solution method.

Flexibility is also important in mathematics learning, especially in problem solving (National Advisory Panel, 2008). National Research Council (2001) defines procedural fluency as knowledge of when and how to use procedures and skills to use them flexibly, accurately, and efficiently. From this opinion, flexibility is an important component in procedural fluency. However, it is not clear how flexibility must be placed within a conceptual or procedural knowledge. Is the flexibility part of procedural knowledge (Star, 2005) or part of conceptual knowledge (Baroody, Feil, \& Johnson, 2007) or integration of conceptual knowledge with procedural (Baroody \& Dowker, 2003)?. This research follows the opinion that flexibility is the integration between conceptual and procedural knowledge. Conceptual and procedural knowledge has a stable two-way relationship and is not moderated by prior knowledge (Star, Rittle-Johnson, \& Scheneider, 2011).

Flexibility is assessed as the ability to solve problems in more than one solution and success in choosing the most appropriate procedure to solve the problem (Verschaffel, 2009). With flexibility, students will tend to develop and adapt procedures to solve new problems that are in front of them.

Rittle, Johnson and Star (2007) revealed that students who are learning algebra can simultaneously gain conceptual knowledge, procedural knowledge, and flexibility. Furthermore, Newton and Star (2010) say that two solutions to solve a linear equations in ove variable if the first solution uses the distributive property of multiplication and the second solution uses the addition of similar terms in the first line of solution, the two solutions can be said as two different solution. While choosing the right solution in this research refers to the subject itself. If for an expert to say the right solution is to use the fastest strategy, a few completion steps, and use a very easy way. Then it can be different from students who say that the right solution is the steps they understand. Thus, this study uses linear equations in one variable material to find out how students are flexible.

The following is an example of solving a linear equations in one variable using two different solution:

Solve the following questions in more ways than one solution!

$$
\begin{aligned}
& \text { 1. } 3(x+1)=15 \\
& \text { 2. } \frac{2}{3}(x+5)=8
\end{aligned}
$$

Solution:

$$
\begin{aligned}
& \text { 1. Solution I. } \\
& 3(x+1)=15 \\
& 3 x+3=15 \\
& 3 x=12 \\
& x=4 \\
& \text { 2. Solution I. } \\
& \frac{2}{3}(x+5)=8 \\
& \frac{2}{3} x+\frac{10}{3}=8 \\
& \frac{2}{3} x=\frac{14}{3} \\
& x=7
\end{aligned}
$$

However, this study describes the flexibility of students in solving linear equations in one variable. Describing the profile of students' flexibility in solving linear equations in one variable can provide information so that the design of teachers in learning, especially mathematics can increase student flexibility.

\section{METHODS}

This research is a descriptive study with a qualitative approach that aims to describe the profile of students' flexibility in solving linear equations in one variable. The subjects of the study were three students of grade VIII of a Junior High School in Surabaya. The selection of subjects uses sampling with maximum variation based on the many solutions used according to the definition of flexibility which emphasizes solving in more than one different solutions so that one student can solve the questions one solution, one student can solve the questions in two solutions, and one student who can solve the questions in three solutions. The research instrument consisted of the researcher as the main instrument, test questions, and interview guidelines as supporting instruments. Data collection methods used were taskbased interviews. Analysis of research data is based on 
indicators of flexibility through data reduction, data presentation, and making conclusions.

The following instrument flexibility test questions are used:

Complete each of the following equations with more than one solution!

$$
\begin{aligned}
& \text { a. } 3(x+1)+2(x+1)=20 \\
& \text { b. } \frac{7}{2}(x-2)-\frac{3}{2}(x-2)=16
\end{aligned}
$$

To be able to solve the problems above, the subject is required to know what properties can be used in solving the problem. Subjects are required to use procedural knowledge and conceptual knowledge to help find various solutions in solving it.

Indicators of flexibility according to Newton and Star (2010) are "The ability to solve problems in more than one different solution and the success of choosing the right procedure to solve these problems". Referring to the statement, the indicators of flexibility in this study are:

Table 1. Indicators of Student Flexibility in Solving Variable Linear Equations (Adapted from Rittle-Johnson \& Michael

\begin{tabular}{|c|c|c|c|}
\hline $\begin{array}{l}\text { Component of } \\
\text { Flexibility }\end{array}$ & Indicator & Knowledge & Code \\
\hline \multirow{3}{*}{$\begin{array}{l}\text { Being able to } \\
\text { solve linear } \\
\text { equations in one } \\
\text { variable with } \\
\text { more than one } \\
\text { way of solving. }\end{array}$} & $\begin{array}{l}\text { Determine the } \\
\text { method of solving }\end{array}$ & $\begin{array}{l}\text { Conceptual } \\
\text { knowlegde }\end{array}$ & F1 \\
\hline & $\begin{array}{l}\text { Solving linear } \\
\text { equations in a } \\
\text { familiar solution } \\
\text { (commonly used). }\end{array}$ & $\begin{array}{l}\text { Procedural } \\
\text { knowlegde }\end{array}$ & $\mathrm{F} 2$ \\
\hline & $\begin{array}{l}\text { Solving linear } \\
\text { equations in an } \\
\text { alternative } \\
\text { solutions. }\end{array}$ & $\begin{array}{l}\text { Procedural } \\
\text { knowlegde }\end{array}$ & F3 \\
\hline \multirow{2}{*}{$\begin{array}{l}\text { Being able to } \\
\text { choose the right } \\
\text { procedure for } \\
\text { solving linear } \\
\text { equations in one } \\
\text { variable. }\end{array}$} & $\begin{array}{l}\text { Compare the most } \\
\text { effective solutions }\end{array}$ & $\begin{array}{l}\text { Conceptual } \\
\text { knowlegde }\end{array}$ & $\mathrm{F} 4$ \\
\hline & $\begin{array}{l}\text { Choose the most } \\
\text { appropriate } \\
\text { procedure. }\end{array}$ & $\begin{array}{l}\text { Conceptual } \\
\text { knowlegde }\end{array}$ & F5 \\
\hline
\end{tabular}
Schneider, 2014)

\section{RESULTS AND DISCUSSION}

The following is a description of the interview results:
Si jk
Conversation in-jk order by subject $(i)$
$\mathrm{P} i j k$
Conversation in $-j k$ order by the researcher on
the subject $(i)$

\section{Profile of Subjects' Flexibility to Solve Questions in} One Solution (S1)

Flexibility of S1 in questions a

The following is the answer of S1:

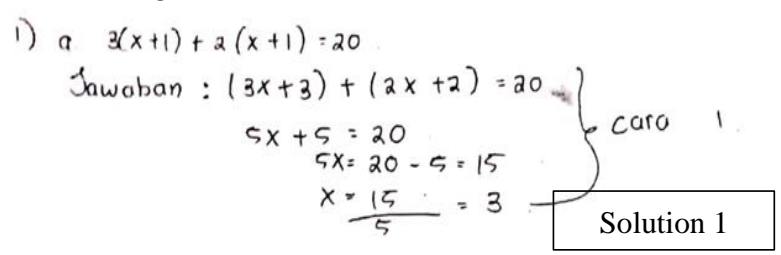

Figure 1. S1 flekxibility test answers in questions a

S1 interview results based on solving the test above:

P1 01 : Why you only used one solution?
S1 01 : I don't know any other, miss and usually also use this, I once explained to the teacher but forgot

P1 02 : What method did you use to solve the problem and why did you choose to use it?

S1 02 : I multiply one by one as usual, miss

P1 03 : Try to explain how you did the first problem!

S1 03 : So this is 3 times $x+1$ in parentheses because the brackets mean multiplied so the result is $3 x+3$ plus 2 times $x+1$ in parentheses $2 x+2$ equals 20 . Then there are $x$ combined together $5 x$ then 3 plus 2 becomes 5 then the 5 segments are moved to the right so $5 x=20-5=15$. Then 15 divided by 5 results 3 (F1 question a)

P1 04 : Usually use this method?

S1 04 : Yes you usually use this (F2 question a)

Based on the interview data and the results of the S1 written test, the following attributes can be described:

S1 subjects solving on the problem in only one solution with the reason that solution is the only known and understood by the subject. The subject also said that the teacher had given information about another solution but the subject claimed to forget the solution. The subject chooses the settlement method that is commonly used to solve problems. In problem a, the solution is to use the distributive property of multiplication to the sum and then to add the same term followed by the two segments minus a number so that the variables and constants are in different segments and then divided by the coefficient $x$ to find the value of $x$ (S1 03). This solution is the commonly used solution by subjects in solving linear equations in one variable problem (S1 04).

\section{Flexibility of $\mathrm{S1}$ in questions $b$}

The following is the answer of S1:$$
\text { 1) b } \frac{7}{2}(x-2)-\frac{3}{2}(x-2)=16
$$$$
\text { Jawaban } \begin{aligned}
3,5(x-2)-1,5(x-2)=16 \\
3,5 x-7-1,5 x+3=16 \\
2 x-4=16 \\
2 x=16+4 \\
x=\frac{20}{2}=10
\end{aligned}
$$

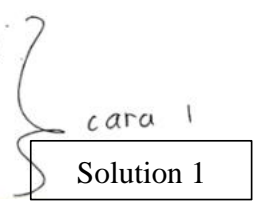

Figure 2. S1 flexibility test answers in questions $b$

$\mathrm{S} 1$ interview results based on solving the test above:

$$
\begin{array}{ll}
\text { P1 } 05: \text { Then for question b, how do you do it? } \\
\text { S1 } 05: \text { Just like questio a, I just changed to comma (,), so }
\end{array}
$$
it's easier so there are no fractions, but after that, the method is the same.

P1 06 : Try to explain in more detail how you solved questio $b$ !

S1 06 : So at first the fractions I made were commas, then I multiply one by one like a problem until I found the $\mathrm{x}$ result (F1 question b)

P1 07 : Usually you change the fraction to the solution if you meet something like this?

S1 07 : Yes, miss, because I think it's easier (F2question b)

P1 08 : What do you think is the difference between settlement number $a$ and question $b$ ?

S1 08 : Actually it's almost the same, just because the second is fraction so it becomes rather difficult.

P1 09 : There is no other way for you to solve this problem

S1 09 : No sis, I'm afraid I'll get confused

Based on the interview data and the results of the S1 written test, the following attributes can be described: 
In question $\mathrm{b}$, the settlement method used is to change the fraction of the equation into a decimal, then the distributive multiplication is done to the subtraction then add the same term followed by the two segments minus the number that makes the variables and constants are in different segments and then divide by the coefficient $x$ to find the value from $x$ (S1 06). The solution used by S1 to solve problem $\mathrm{b}$ is almost the same as problem solving a, it's just that the subject changes the fraction numbers that exist in the problem into decimal numbers with the reason it's easier to do (S1 07).

The subject cannot find other solutions that can be used in solving problems in questions a and questions $b$ (S1 09). S1 does not have the motivation to explore alternative solutions that might be more effective than a single solution that is owned by the subject.

\section{Profile of Subjects' Flexibility to Solve Questions in Two Solutions (S2)}

\section{Flexibility of $S 2$ in questions a}

The following is the answer of S2:

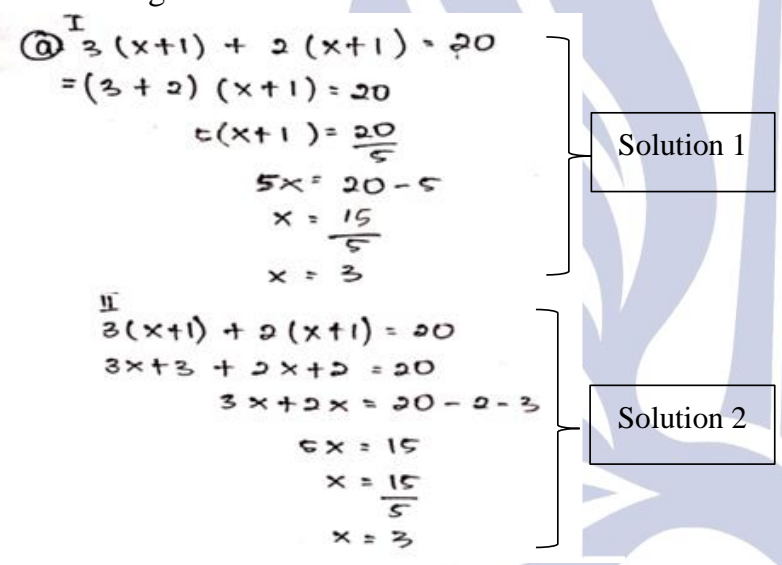

Figure 3. S2 flekxibility test answers in questions a

$\mathrm{S} 2$ interview results based on solving the test above:

P2 01 : In working on the problem, what method that you use and try to tell me why you chose this method?

S2 01 : If I use the a solution 1, I combine the numbers because the ones in the same brackets, I get this method from my teacher, if I use solution 2 only one time at a time. Then the problem $b$ was all of the times I was the only one I had eliminated first the fractions so it was easier

P2 02 : Why choose to use these methods?

S2 02 : Yes, I know it's Miss, but normally I only use one by one

P2 03 : Try to explain how you worked out the problem for the first equation!

S2 03 : These 3 and 2 are combined together because they add up the same numbers in the enclosure, then multiply $(x+1)$ down, then the answer $5(x+$ $1)=20$. Then 5 times $x$ times the results $5 x$ plus 5 times 1 the result is 5 , this is I immediately moved the 5 segments so the sign becomes less $55 x=20-5,20-5$ results 15 . Then $x$ equals 15 divided by 5 from $5 x$ it original multiplication because it was moved to a division then found the result $x=3$ (F1 question a)

P2 04 : For the second way, how do you do it?
S2 04 : The second is $3 x$ of 3 times $x$ plus 3 times 1 the result is 3 plus 2 times $x$ is equal to $2 x$ plus 2 times 1 the result is 2 equal to 20 . Then $3 x$ plus is equal to $2 x$ equal to 20 minus 2 minus 3 , then $3 x$ plus $2 x$ is $5 x$ the result is the same with $20-2-$ 3 the result is 15 . Then $x$ equals 15 divided by 5 equals 3 (F1 question a)

P2 05 : Do you understand the way you are using?

S2 05 : First of all, I just don't know how much I understand, I got it from my teacher. The second is the one that I understands ( F3 question a)

P2 06 : Which solution do you usually use?

S2 06 : This is my second one-on-one like (F2 question a)

P2 07 : For question a, which method do you think is more efficient and why?

S2 07 : The second solution, because you understand better (F4 question a)

P2 08 : If told to choose the most appropriate way to solve which way?

S2 08 : The second one I understand and usually also use it (F5 question a)

Based on the interview data and the results of the S2 written test, the following attributes can be described:

The settlement method used by the subject comes from the subject's experience of the teacher, usually subjects use the distributive method when encountering questions that are similar to the test questions Solution for the first solution is to add the same type of terms then use the distributive property of multiplication to the sum which is continued by reducing the two segments with a number of seconds until the variables and constants are in different segments and then division of the two segments with coefficients from $x$ until the value of $x$ is found (S2 03 ). In the second solution, the settlement method used is to use the distributive property of multiplication to the sum followed by the addition of similar terms and then subtracting the two segments with numbers that make the variables and constants to be in different segments to further divide the two segments with the coefficient of $x$ to get the value of $x$ (S2 04).

The commonly solution used by subjects in solving these questions is the second solution (S2 06). Whereas the alternative solution used by the subject is the first method which is the result of the subject's experience from his teacher (S2 05).

OWhen comparing the two methods used, the subject revealed that the more efficient solution to use is the second solution (S2 07). This solution is the most appropriate procedure chosen by the subject in solving question s because it is easy to understand (S2 08).

\section{Flexibility of $S 2$ in questions $b$}

The following is the answer of S2: 


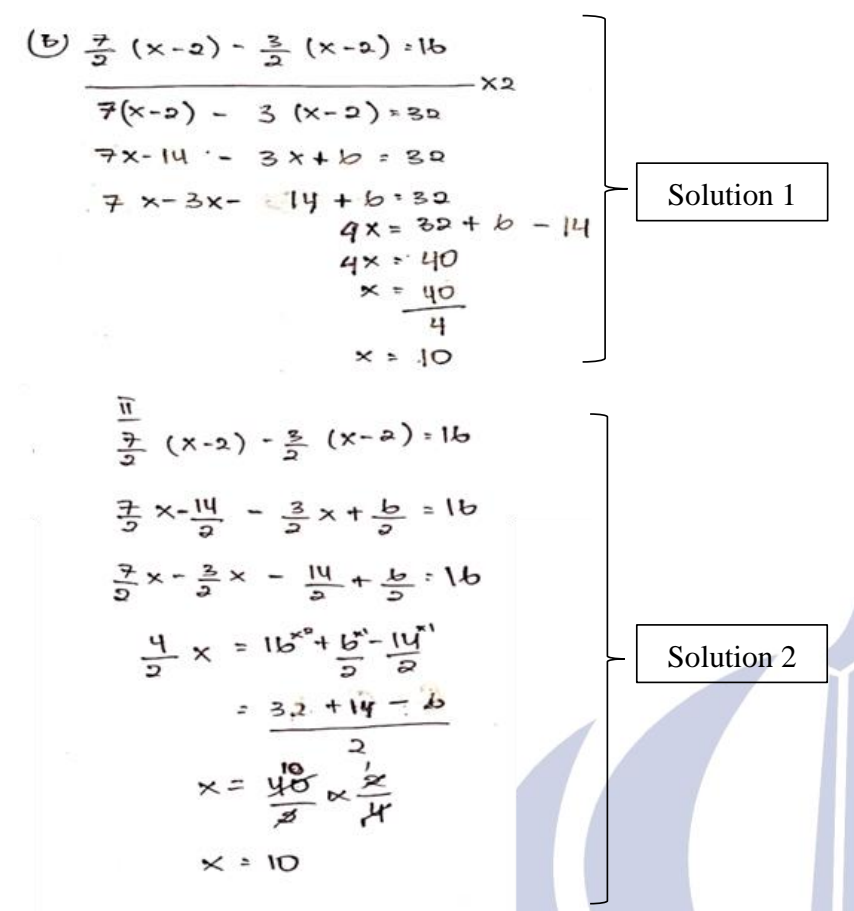

Figure 4. S2 flekxibility test answers in questions $b$

S2 interview results based on solving the test above:

P2 09 : Then try to explain how you did the question b!

S2 09 : For the first solution, I $\mathrm{f}$ remove the denominator so that it's easy with 2 times the two segments, then crossed out 2 only $7(x-2)$ minus $3(x-2)$ equals 16 times 2 the result is 32 . Then 7 times $x$ is 7 times 7 min 14 of $7 \times(-2)$ minus $3 x$ then this -3 times -2 the result is 6 then equal to 32 . Then the variables are put together to be $7 x-$ $3 x-14+6=32$ the result is $4 x$ equal to 32 minus 6 and 14 is moved to the segment so negative 6 plus 14, then $4 x=40$ and $x$ equals 40 for 4 the result is 10. (F1 question b)

P2 10 : Then how do you do the second solution for number $\mathrm{b}$ ?

S2 10 : The second solution I used to be $\frac{7}{2}$ times $x$ results $\frac{7}{2} x$ times $\frac{7}{2}$ times -2 results $-\frac{14}{2}$ then $-\frac{3}{2}$ times -2 results were $6 / 2$ positive. Then the numbers with variables are put together to become $\frac{7}{2} x-\frac{3}{2} x-$ $\frac{14}{2}+\frac{6}{2}=16$, the result is $\frac{4}{2} x$ equal to 16 and then this one is $-\frac{14}{2}+\frac{6}{2}$ to be moved to the same as $16-\frac{6}{2}+\frac{14}{2}$. The result is $\frac{4}{2} x$ is the same as the variable with no 'per' because there is' per'nya 2 so $\frac{32+14-6}{2}$ the result is $x$ equal to $\frac{40}{2}$ times $\frac{2}{4}$ so $\frac{4}{2}$ in front of $x$ must be multiplied by $2 / 3$ so that it produces $x=10$ (F1 question b)

P2 11 : What method do you usually use when encountering questions like this?

S2 11 : The first solution miss, I remove the fragments first to make it easier then I multiply one by one (F2 question b)

P2 12 : If in solution 2 you use what method?

S2 12 : I multiply one by one, then I group up to find how many $x$ (F3 question b)

P2 13 : Which number $b$ is more efficient for you?

S2 13 : The first solution is easier because you already have no fractions (F4 question b)

P2 14 So if asked to choose you will choose which way do you think is most appropriate?

S2 14 Method 1 for understanding more, calculating it is also easier (F5 question b)
P2 15 : When you are working on question b. Did you help with the settlement at number 1 ?

S2 15 : Yes, it helps from the way it looks like the model, because the numbers are replaced

P2 16 : Why didn't you apply Method 1 to Method 1 for Problem 1?

S2 16 : Oh yes, but I'm afraid I can't calculate because of the fraction

P2 17 : Which of the two questions do you find more difficult?

S2 17 : Question b

P2 18 : Why?

S2 $18:$ : Because the questionr $b$ is a fraction

P2 19 : There is no other way that can be used to solve this problem

S2 19 : No miss

Based on the interview data and the results of the $\mathrm{S} 2$ written test, the following attributes can be described:

In problem $b$ the settlement method used for the first solution is the two segments multiplied by the denominator of fractions then using the distributive property of multiplication to the reduction followed by the addition of similar terms then the two segments are subtracted by numbers that make the variables and constants to be in different segments until the value $\mathrm{x}$ is searched for divides the two segments by the coefficient $\mathrm{x}$ (S2 09). Whereas the settlement method for the second method is to use the multiplicative disributive properties on the subtraction then add the same term followed by the two segments minus the numbers that make the variables and constants to be in different segments until the multiplication of the two segments with the inverse number of the coefficient $x$ is to be found the value of $x$ (S2 10).

The commonly used solution by subjects in solving problems is the first solution with the reason that if the fraction is removed first then the next calculation will be easier (S2 11). While the alternative solution used is the second solution (S2 12). The subject also chose the first solution as a more effective solution because it was easier to do (S2 13). Furthermore, according to the subject the first solution is also the most appropriate one to solve the problem (S2 14)

In solving question $\mathrm{b}, \mathrm{S} 2$ feels helped by question a from the solution it works because the model is similar so that the method used will also be the same. However, when asked to solve other ways that might be used to solve the problem the subject claimed not to know even though the subject only applied the distributive method in both solutions in question $b$ while the method of adding the same ethnic terms contained in question solving a was not applied to question $\mathrm{b}$.

\section{Profile of Subjects' Flexibility to Solve Questions in Three Solutions (S3) \\ Flexibility of $\mathrm{S3}$ in questions a}


The following is the answer of S3:

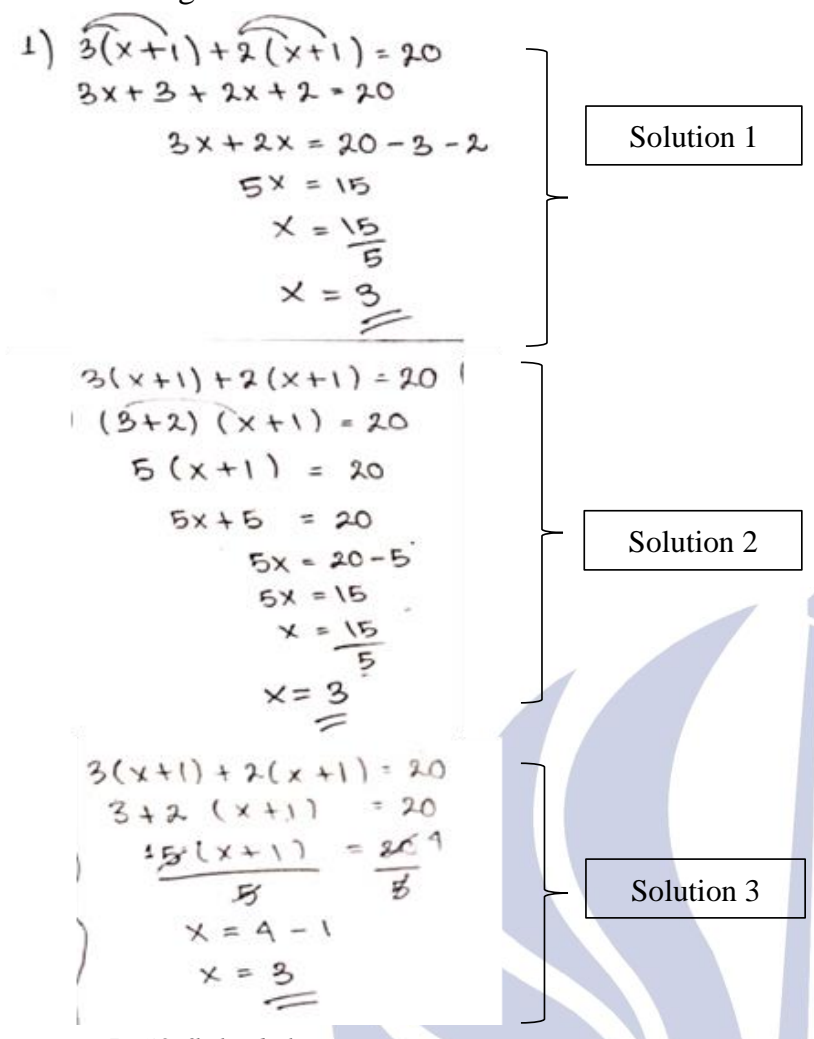

Figure 5. S3 flekxibility test answers in questions a

S3 interview results based on solving the test above: P3 01 : What method of settlement do you use to solve these problems?

S3 01 : This is one of the times I am the only one I have grouped

P3 02 : Why did you choose to use these methods?

S3 02 : As far as I know, these methods can be used from my teacher because this is only one variable

P3 03 : For equation a, try to explain how to do the problem

S3 $03: \quad 3 x$ is obtained from 3 times $x$ right, this is marked by parentheses multiplied, the result is 3 times, then 3 times 1 is the result 3 . Then the next one uses the same method which is 2 times $x$ the result is $2 x$ and 2 times 1 is the result 2 is equal to 20 . Then $3 x$ and $2 x$ You have the same variable $x$, so you can then add numbers 3 and 2 to the left, so it becomes negative. $3 x$ plus $2 x$ equals $5 x$ then 20 minus 3 minus 2 equals 15 . x equals 15 per $5, x$ equals 3. (F1 question a)

P3 04 : Then for the second solution, try to explain how your process works!

S3 04 : This $(x+1)$ because the same is put together, then the front is also put together so 3 plus 2 results are 5 . Then 5 times $(x+1)=20$, then 5 times $x$ is equal to $5 x$ then 5 times 1 is equal to 5 . Then this the $5 x+5$ is put 5 to the right the sign changes to negative, then $5 x=20-5=15, x$ equals 15 per 5 equals 3 . So the result $x$ equals 3 (F1 question a)

P3 05 : For the third solution, how do you do it?

S3 05 : Almost the same as the second method, it's just that after finding $5(x+1)=20$, these are my two direct segments for 5 so that they run out, so only $x+1=4$ then the result $x=3$ (F1 question a)

P3 06 : Which deck do you usually work on?

S3 06 : The first solution, if usual (F2 question a)

$\mathrm{P} 307$ : If the second and third solution s are rarely used?
S3 07 : It's almost never possible miss, I just know from my teacher (F3 question a)

P3 08 : So after working in more than one way, do you think the most effective way, for example, the easiest and fastest way is the name?

S3 08 : In my opinion, the easiest way is in the first method, but if the fastest, the third method (F4 question a)

P3 09 : For example, if you have to choose one of the two methods, which method will you choose?

S3 09 : The first one, so I'm not confused (F5 question a)

Based on the interview data and the results of the S3 written test, the following attributes can be described:

The settlement method used is derived from the subject's experience when learning the linear equation in one variable by the teacher. The solution for question a in the first solution is to use the distributive property of multiplication to the sum then add the same term then subtract the two segments with numbers that make the variables and constants to be in different segments followed by the division of the two segments with the coefficient of $x$ to find the value of $x$ (S3 03). For the second solution, the settlement method used is the addition of similar terms and then using the distributive property of multiplication to the sum then the two segments are subtracted by numbers that make the variables and constants to be in different segments followed by the division of the two segments with the coefficient $\mathrm{x}$ until a value of $x$ is found (S3 04). Whereas for the third method, the settlement method used is to add the same term then divide the two segments with the coefficient of $x$, then the two segments minus the number that makes the variables and constants are in different segments until a value of $x$ is found ( $\mathrm{S} 305)$.

The commonly used solution for subjects to encounter similar problems is the first method (S3 06). Whereas the second and third solutions are alternative solutions obtained from the subject's experience (S3 07).

According to subject $\mathrm{S} 3$, the most effective solutions to do is the first solutions but the subject also said there is another solution which is the third solution as the fastest solution because there are fewer steps (S3 08). However, subjects still choose the first solution as the most appropriate solution to avoid confusion in solving problems (S3 09).

\section{Flexibility of $S 3$ in questios $b$}

The following is the answer of S3: 
2)

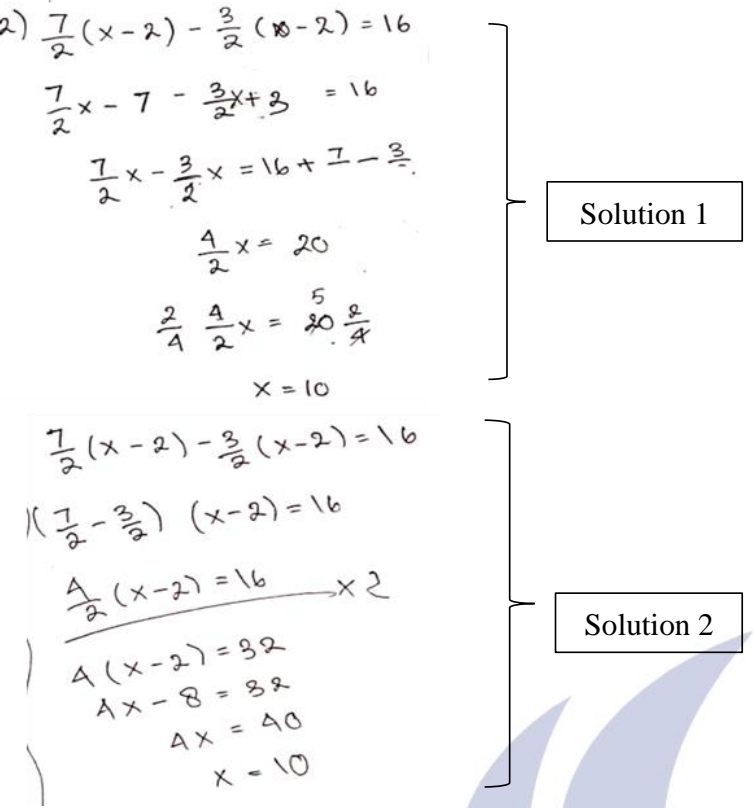

Figure 6. S3 flekxibility test answers in questions $b$

S3 interview results based on solving the test above: P3 10 : For number b, how do you do it? Try to explain!

S310 : This is because $\frac{7}{2}$ times $(x-2)$ is the same as $\frac{7}{2} x$ then $\frac{7}{2}$ times 2 is the same 2 so the result is crossed out with 7 negative signs. Then this $\frac{3}{2}$ times $x$ equals $\frac{3}{2} x$ the sign is negative, then the $-\frac{3}{2}$ times -2 is the same as rich, $\frac{7}{2}$ so the number 2 is crossed out with 3 plus (positive sign) because negative times negative is 16 Then $\frac{7}{2} x$ is reduced by $\frac{3}{2} x$ because it's the same $x$, then in the right segment there are 16 and the 7 and 3 in the left are moved to the right, because 7 negative say is moved so it's positive then the 3 because it's positive is moved so negative. Then the ones that are $\frac{7}{2}$ and $\frac{3}{2}$ because the numbers 2 are the same (the denominator are the same) so you can immediately deduct 7 minus 3 , the result is 4 so $\frac{4}{2} x$ equals $16+7+3=30$. Then this is my two times segment $\frac{2}{4}$ so that the $\mathrm{x}$ runs out. So the result is $x=10$. (F1 question b)

P3 11 : Then for the second way how do you do it?

S311: This is the same as how to do the second one in number 1 right $(x-2)$, the same is written down again, then the front one is put together so $\left(\frac{7}{2}-\frac{3}{2}\right)$ the result is $\frac{4}{2}$ times $(x-2)$ is the same as 16 , then I multiply everything 2 (F1 question b)

P3 12 : Usually when you work on things like this, which one do you use?

S3 12 : The first one miss (F2 question b)

P3 $13:$ If the second method is rarely used?

S3 13 : Yes (F3 question b)

P3 14 : What do you think is the most effective solution to work on this problem?

S3 14 : The first solution, miss, as I understand it (F4 question b)

P3 15 : Suppose you were told to work on this problem using just one method. Which solution would you choose?

S3 15: The first solution (F5 question b)

P3 16 : When you are working on the second problem, are you helped by not solving the first question?
S3 16 : Helped sis, it's actually the same, but the second one is more difficult because the second one is a fraction

P3 17 : Is there any solution to solve the question?

S3 17 : I think nothing

Based on the interview data and the results of the S3 written test, the following attributes can be described:

In question $b$, the settlement method used by subject S3 for the first solution is to use the distributive property of multiplication to subtraction then add the same term then the two segments are subtracted by the number that makes the variable and constant are on different segments. $x$ until the value of $x$ is found in the equation (S3 10). Whereas for the second solution, the solution is the addition of similar terms then removes the fraction coefficient with the two segments multiplied by the denominator of the fraction and then uses the distributive property of multiplication to the continued reduction of the two segments minus the number that makes the variables and constants to be in different segments then the division of the two segments with coefficients from $x$ to produce the value $x$ (S3 11).

The commonly used solution for subjects to solve equation question $b$ is the first solution (S3 12). While the alternative solution used is the second solution where the method is rarely used by the subject (S3 13). Regarding the use of a more effective solution, the subject chooses the first solution with a more understanding reason to use that solution (S3 14). Likewise in choosing the most appropriate way the subject also chooses the first solution to be used (S3 15).

In solving on question $b$, the subject said it was helped by solving question a because of the same question. This is evidenced by the success of the subjects applying the method of solving solution 1in question a to solution 1 in question $b$ and solution 2 in question a to solution 2 in question $b$. However, the subject feels about $b$ is more difficult because there are fractions in it.

Profile of Students' Flexibility in Solving Linear Equations in One Variable

In general, the method to solving linear equtions in one variable chosen by students is to use the distributive property of multiplication with the addition or subtraction in the first line as the first solution and then the addition of similar terms in the first line in completion as the second solution and so on. The commonly used solution by students when encountering questions that are similar to test questions is to use the distributive property of multiplication while the sum of similar terms which is an alternative solution is rarely used. Explaining the concept of the solution is not very visible because it only says that thesolution is the experience of the subject received from the previous class. 
When comparing the solution used, the commonly used method is chosen as the most appropriate solution for them even though there are those who have succeeded in finding a faster solution. That is because students prefer to use solution that they understand and are commonly used in solving problems to avoid confusion. This is consistent with the findings of Blote, et al (2001) which said that students would tend to use the methods commonly used to solve a problem. Students also say that question $b$ is more difficult to do because it contains fractions in it. This is evidenced by the student's choice to eliminate the fraction at the beginning by multiplying the two segments with the denominator of the fraction itself.

The test questions that are given have a similar model, except that the coefficient used is fraction. But not all students can consider the two questions as a unit that should be applied in solving problems a can be applied to solve problems $b$. This is because students find fractions more difficult to do.

\section{CONCLUSION AND RECOMENDATION}

\section{Conclusion}

Based on the results of the analysis and discussion, students' flexibility in solving one linear variable equations is as follows. The ability to solve problems with more than one solution of solving begins with the solution that commonly used when encountering similar problems as the first method and the solution students obtain based on the experience of their teacher as an alternative solution. Alternative solutions used are also rarely chosen by students in solving problems. Students also choose the completion procedure that is commonly used as the most appropriate solution. Even though students have gained knowledge about alternative methods, students tend not to always use them because they have fluency with a particular solution of solving or a single method.

Fluency with a single strategy can be the obstacle of flexibility. The use of the usual method of settlement tends to make students choose to use that method even though there are other more effective solutions to solve it. The reason students choose the method that is commonly used as the most appropriate solution for them is because it is a solution that they understand and to avoid confusion.

The two-way relationship between procedural knowledge and conceptual knowledge in flexibility allows for one type of knowledge to support the increase in knowledge of another. Furthermore, comparing, explaining themselves, exploring can encourage increased procedural and conceptual knowledge in flexibility.

\section{Recomendation}

In learning linear equations in one variable students should be given space to identify and choose the most effective solutions to solve linear equations in one variable while providing arguments related to that choice.

\section{REFERENCES}

Baroody, A. J., \& Dowker, A. 2003. The development of arithmetic concepts skills: Constructing adaptive expertise. Mahwah, NJ: Lawrence Erlbaum.

Baroody, A. J., Feil, Y., \& Johnson, A. (2007). An alternative reconceptualization of procedural and conceptual knowledge. Journal for Research in Mathematics Education, 38(2), 115-131.

Blote, A. W., Van der Burg, E., \& Klein, A. S. 2001. Students' flexibility in solving two-digit addition and substraction problems: instruction effects. Journal of Educational Psychology, 93, 627-638.

Byrnes, J. P., \& Wasik, B. A. 1991. Role of conceptual knowledge in mathematical procedural. Developmental Psychology, 5, 777-786.

D. Dieks. 2014. The Flexibility of Mathematics. Netherlands: Utrecht University.

Hersh, Reuben. 2019. Mathematics. Mexico: University of New Mexico.

National Research Council. 2001. Adding it up: Helping children learn mathematics. In J. Kilpatrick, J. Swafford, \& B. Findell (Eds.), Mathematics learning study committe, center for education, division of behavioral and social sciences, and education. Washingson, DC: National Academies Press.

National Council of Teachers of Mathematics. 2006. Curriculum focal points for prekindergarten through Grade 8 mathematics: A quest coherence. Reston, VA: National Council of Teachers of Mathematics.

Newton, K. J. (2008). An extensive analysis of preservice elementary teachers' knowledge of fractions. American Educational Research Journal, 45(4), 1080-1110.

Newton, Kristie Jones \& Star, Jon R. 2010. Understanding the Development of Flexibility in Struggling Algebra Students. Mathematical Thingking and Learning. Vol. 12. 283-305.

Rittle-Johnson, B., Siegler, R. S., \& Alibali, M. W. 2001. Developing conceptual understanding and procedural skill in mathematics: An iterative process. Journal of Educational Psychology, 93(2), 346-362.

Rittle-Johnson, B., \& Star, J. R. 2007. Does comparing solution methods facilitate conceptual and procedural knowledge? An experimental study on learning to solve equations. Journal of Educational Psychology, 99(3), 561-574. 
Rittle-Johnson, B,. \& Star, J. R. 2009. Compared to what? The effects of different comparisons on conceptual knowledge and procedural flexibility for equation solving. Journal of Educational Psychology, 101(3), 529-544.

Rittle-Johnson, B., Star, J. R., \& Durkin, K. 2009. The importance of familiarity when comparing examples: Impact on conceptual and procedural knowledge of equation solving. Journal of Educational Psychology, 101(4), 836-852.

Rittle-Johnson, B., Star, J.R., \& Durkin, K. 2012. Developing procedural flexibility: Are novices prepared to learn from comparing procedures? British Journal of Educational Psychology, 82(3), 436-455.

Schneider, M., Rittle-Johnson, B., \& Star, J.R. 2011. Relations among conceptual knowledge, procedural knowledge, and procedural flexibility in two samples differing in prior knowledge. Developmental Psychology, 47(6), 1525-1538.

Siegler, R.S. 2000. The rebirth of children's learning. Chiid Deveiopment, 71, 26-35.

Star, J. R. 2005. Reconceptualizing procedural knowledge. Journal for Research in Mathematics Education, 36(5), 404-411.

Star, J. R., \& Seifert, C. 2006. The development of flexibilityu in equation solving. Comtemporary Educational Psychology, 31, 280-300.
Star J R. 2006. Flexibility in the Use of Mathematical Procedure. San Diego: American Educational Research Education.

Star, J. R. 2007. Foregrounding procedural knowledge. Journal for Research in Mathematics Education, 38(2), 132-135.

Star, J.R., \& Rittle-Johnson, B. 2008. Flexibility in problem solving: The case of equation solving. Learning and instruction, 18(6), 565-579.

Star, J. R., \& Newton, K. J. 2009. The nature and development of experts' strategy flexibility for solving equations. ZDM - The International Journal on Mathematics Education, 41, 557-567.

Sugiyono. 2010. Metode Penelitian Kualitatif. Bandung: UPI.

Tim Penyusun Buku Pedoman Penulisan Skripsi. 2014. Pedoman Penulisan Skripsi Program Sarjana Starta Satu (S-1) Universitas Negeri Surabaya. Surabaya: Universitas negeri Surabaya

Verschaffel, L., Luwel, K., Torbeyns, J. \& Van Dooren, W. 2009. Conceptualizing, investigating, and enhancing adaptive expertise in elementary mathematics education, European Journal of Psychology of Education, 24: 335-359.

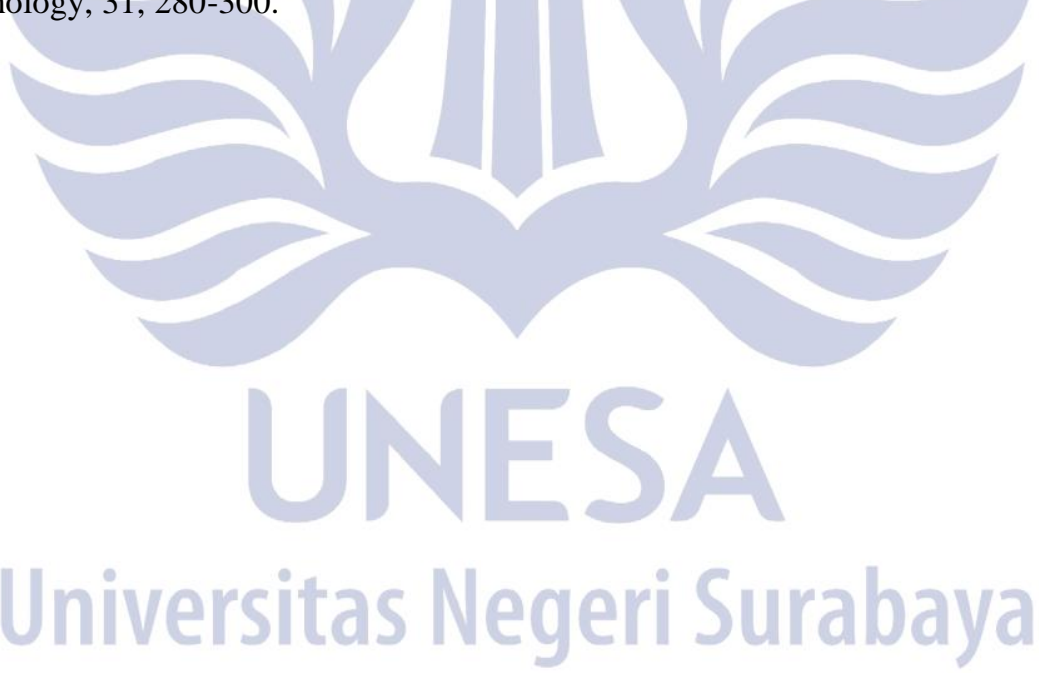

